\title{
Exploration and Characterization of Local Glutinous Rice Germplasm (Oryza sativa L. Var. Glutinosa) three Regencies in west Sumatra
}

\author{
Feri Hendriawan ${ }^{1}$, Nasrez Akhir ${ }^{2}$, Yusniwati ${ }^{3}$
}

\author{
${ }^{1}$ Department of Agriculture, Andalas University, Indonesia \\ Email: ferihendri1987@gmail.com \\ ${ }^{2}$ Department of Agriculture, Andalas University, Indonesia \\ Email: nasrezaakhir@gmail.com \\ ${ }^{3}$ Department of Agriculture, Andalas University, Indonesia \\ Email: yusniwatibismi@gmail.com
}

\begin{abstract}
The purpose of this research was to identify and characterize the morphology of local glutinous rice germplasm three regencies in West Sumatera. This research was conducted in May - August 2019 in three regencies of West Sumatera. The result of this research indicate that glutinous rice plants can grow to a height of 1086 meters above sea level with a coordinate point 0'33'27" South Latitude and 100'32'28" East Longitude. The highest plants are found in white glutinous rice 'Puluik Tinggi' that is 150,03 cm and the lowest plants are found in black glutinous rice 'Puluk Itam' that is 90,6 cm. Observation of the highest amount of leaves found in white glutinous rice germplast 'Pulut Putih' as many as 60,4 strands/clumps while the smallest amount of leaves obtained in white glutinous rice germplasm 'Anak Ulek' as many as 51,3 strands/clumps. The fastest harvest period in white glutinous rice germplast 'Pulut Putih' during 120 days and the longest harvest period in white glutinous rice 'Kuku Balam', 'Puluik Tinggi', 'Puluk Putih' and red glutinous rice 'Puluk Sirah' during 165 days. There are 2 germplasm that has the highest similarity coefficient that is $42 \%$ between white glutinous rice 'Anak Ulek' dan 'Pulut putih', this means that both germplasm have a close kinship.
\end{abstract}

Keywords-Morphology, Exploration, Characterization, Glutinous Rice.

\section{INTRODUCTION}

Indonesia is an agricultural country that has the most diversity of rice plants. Glutinous rice is one of the thousands of rice varieties. What distinguishes between glutinous rice with other rice plant varieties is a high amylase content and low amylopectin. Kadan et al. (1997), the carbohydrate content of glutinous rice is very high compared to protein, fat and vitamins. These carbohydrate have an important role in determining the characteristics of food ingredients such as taste, color, texture and others. Starch contained in glutinous rice amylopectin is very high around $97 \%$ with low amylose.

The superiority of glutinous rice compared to rice varieties generally lies in the morphological characteristics of glutinous rice plants, where it have a rough leaf surface so that leaf insects do not like pests. Thus, it is necessary to identify and characterize a variety of glutinous rice germplasm so that it can be utilized by plant breeders in assembling superior varieties. IRRI (1995), identifying germplasm of local varieties that have superior genes makes it easier for plant breeders to obtain recombinant genotypes that have superior character in accordance with the target of improved varieties. In general, the use of local varieties as crossing parents produces derivatives with very diverse morphological and agronomic characteristics, so that a more intensive selection process is needed.

There are still many local glutinous rice germplasm that have not yet been identified and characterized. The community has begun to rarely cultivate it, there is no serious attention from the government to prevent it and fear of extinction of local glutinous rice germplasm is a source of problems for plant breeders in germplasm conservation programs. Efforts should be made to save the diversity of local glutinous rice germplasm by exploring and characterizing local glutinous rice germplasm in the regions. Daradjat, et al. (2008), the genetic diversity of a plant species can decrease, because of the planting and expansion of new superior species so that very diverse local species will be urged or even disappear. Scarcity of genetic resources can also occur due to the process of selection and refining of diverse forms of local varieties to form homogeneous landraces. 
West Sumatra Province has several rice production centers, but for this sticky rice there are only a few regions. Not all rice production center areas, the people also plant glutinous rice plants. This is influenced by the community's traditions in the area and the community's need for glutinous rice.

Based on the above, identification and characterization of glutinous rice germplasm was carried out by observing morphological characterization. The purpose of this study was to determine, identify and characterize germplasm from local glutinous rice plants in three regencies in West Sumatra.

\section{MATERIALS AND METHODS}

This research was conducted from May to August 2019. The research took place in three different elevation districts in West Sumatra Province, namely regencies of Agam, Padang Pariaman and Tanah Datar. This research was conducted by survey method, using purposive sampling technique. Morphological characterization of glutinous rice plants refers to the Description of Varieties based on research by the Indonesian Center for Rice Research and Bioversity International, IRRI and WARDA. Qualitative data obtained from morphological observations carried out analysis of variability (variability) which aims to see the level of diversity of glutinous rice plants, using the formula Steel and Torrie.

Similarity analysis on morphological characters was carried out to see the pattern of grouping all of the glutinous rice germplasm. This analysis was carried out by calculating the similarity coefficient value with the output in the form of a dendogram using the Unweighted Pair Group Arithmatic Average (UPGMA) method using NTSYS (Numerical Taxonomy and Multivariate Analysis System) version 2.02 .

\section{RESULT}

\subsection{Identification and Characterization}

Observations in three regencies that have been designated as research areas obtained 9 germplasm of glutinous rice plants. Details of glutinous rice germplasm per regencies, name regencies, coordinates and height can be seen in Table 1.

\subsection{Morphological Characterization}

Based on observations that have been made for the color of sticky rice plants there are three colors namely green, yellowish green and green with purple lines, while the color of the legs of the stem there are two colors namely green and green with purple lines.

From the observation of leaf morphology, high diversity in leaf ear color, leaf tongue color, leaf color, leaf position, flag leaf angle and number of leaves was found. However, no diversity was found in the shape of the leaf tongue and leaf surface, all glutinous rice plants were found to have the same shape of the leaf tongue which is 2-Cleft (split in two), while the leaf surface of the glutinous rice plant was classified as including the edges of the leaves.

Based on observations that have been made, there is a high diversity of sticky rice roots. The extensive and deep root system will affect the resistance of glutinous rice plants to vulnerability caused by wind. The quality of plant roots is influenced by the availability of nutrients and water, so farmers should pay attention to the time of fertilization and inundation of the fields carefully so that plants grow optimally. Kush (1995), roots of rice plants that are deep and thick, healthy, gripping the soil more broadly and stronger able to hold the plants from being overburdened, also allows more efficient absorption of water and nutrients, when the grain filling stage.

For panicle types there are three variations namely compact panicle types, panicle types between compact and medium, and panicle types between medium and open. While the observation of the shape of the grain there are three variations, namely the shape of the grain is rather rounded, the shape of the grain is medium and the shape of the grain is slim or long. The shape of this grain influences the process of processing grain into rice, not all rice mills are willing to process glutinous rice into glutinous rice, especially black glutinous rice. This is because the form of black glutinous rice grain is long, slim and light. So there is a slight difference in the arrangement of the wind valve and the filter device (filter) on the engine. According to Ramadhan (2006), each process of using a rice milling device must adjust the component of the tool which has different functions to avoid damage to rice and a reduction in the amount of rice. As the function of the wind valve is to separate peeled rice from the skin, this process uses a gust of wind.

The observation of grain color there are five variations, namely yellow straw rice, golden grain, brown yellow straw, brownish brown, yellow straw, brown stripes and yellowish brown grain. The color of this grain cannot be used as a benchmark to determine the color of glutinous rice, because there are grain colors that are both yellow straw brown stripes, but the color of the sticky rice is different, some are white and some are red.

\subsection{Phenotypic Variability of Glutinous Rice Plants}

In this study phenotypic variability of glutinous rice plants was calculated, both quantitative and qualitative characters. The phenotypic variability of 9 germplasm was found with 9 quantitative characters and 17 qualitative characters. Based on the measurement of observational variables for each germplasm by calculating the average value and standard deviation, it is shown in Table 2 and 3. 
In table 2 above, it is known that there are three observational variables from nine quantitative characters that have broad criteria, namely plant height $(\mathrm{cm})$, amylopectin content (\%) and plant age (days). While six quantitative character observation variables have narrow criteria, namely the number of leaves, root length, number of tillers, number of productive tillers and average yield (tons). Fauza (2005), the broad phenotypic variability value means that the phenotypic appearance of the character is more influenced by environmental factors. Narrow phenotypic variability in morphological observation characters cannot be used as a basis for selection in plant breeding activities because selection will be successful or effective if the plant population to be selected has broad variability.

In table 3 above, it is known that there are one observational variables from 17 qualitative characters that have broad criteria, namely the color of grain. While 16 qualitative character observation variables have narrow criteria. Tedianto (2012), broad genetic variability of characters will provide broad phenotypic variability also if the interaction with the environment is high enough. Genetic variability occurs due to the influence of genes and different interactions with their environment. Narrow phenotypic variability cannot be used effectively in plant breeding, but can be expanded with hybridization, mutation and introduction of new germplasm.

\subsection{Ethnobotany}

The glutinous rice seeds used are local seeds that have been cultivated for decades. Giving a name to the local glutinous rice plants is obtained from the plant's unique character and the name of the area where glutinous rice plants are cultivated.

Different regencies have different community traditions and different types of sticky rice are utilized. Nevertheless, there are still some similarities in community traditions in these three regencies, namely the annual tradition called Malamang. This tradition has been carried out by the community for years. The time and type of evening traditions vary in these three regencies in West Sumatra Province.

3.5 Similarity Analysis
The pattern of similarity relationship between glutinous rice plants based on 27 morphological characters of 9 germplasm of glutinous rice plants in three districts with different altitude levels in West Sumatra Province shown in Figure 1, overall data processed using the NTSYS 2.02 program produced a dendogram pattern as shown in Figure 2. Classification of some germplasm occurred because there are similarities in the morphological characteristics of each glutinous rice plant. Swasti, et. al. (2007) states that similarity analysis is used to determine the distance or close similarity between plants by using the morphological properties of a plant.

The results of the similarity analysis are based on similarities in observations of 9 quantitative characters and 17 qualitative characters from 9 glutinous rice germplasm obtained by the similarity coefficient of $0.25-0.43$. The results of the similarity analysis are divided into 2 main groups on the similarity coefficient of 0.25 , namely groups 1 and 2. Group 1 consists of KA-KPKB, KTD-KPPP, KPP-KPPP, KPP-KPAU, KTD-KPK, KA-KPPT and KTD-KMPS meanwhile group 2 consisted of KA-KHPH and KTD-KHPI.

In group 1, KTD-KMPS separated at a similarity coefficient of 0.28 from the other group 1 germplasm. At the similarity coefficient of 0.31 KA-KPPT separates from other group 1 germplasm. In the similarity coefficient 0.33 group 1 germplasm is divided into 2 groups again, namely KA-KPKB and KTD-KPPP in group 1, both of which will be separated in the similarity coefficient of 0.39 . While the other group 1 namely KPP-KPPP, KPP-KPAU and KTDKPK, the similarity coefficient of 0.39 KTD-KPK will be separated from KPP-KPPP and KPP-KPAU. At the end of group 1 there was a similarity between the KPP-KPPP and KPP-KPAU on the similarity coefficient of 0.43 . For group 2 between KA-KHPH and KTD-KHPI are separated at the similarity coefficient of 0.36 . According to Syukur, et. al. (2012), the greater the similarity coefficient number, the greater the similarity level between the plants being compared and this shows the closer kinship level. Conversely, the smaller the coefficient of similarity, the smaller the level of similarity of plants and this shows the farther level of kinship.

\section{FIGURES AND TABLES}

Table 1. Details of Germplasm per Regency, District, Coordinates and Altitude

\begin{tabular}{|c|c|c|c|c|c|}
\hline \multicolumn{2}{|c|}{ Location } & \multirow{2}{*}{$\begin{array}{c}\text { Name of } \\
\text { Germplasm }\end{array}$} & \multicolumn{2}{|c|}{ Coordinates } & \multirow{2}{*}{$\begin{array}{c}\text { Altitude } \\
\text { (amsl) }\end{array}$} \\
\hline Regency & District & & South Latitude & East Longitude & \\
\hline Agam & IV Koto & KA-KPKB & $0^{\circ} 02^{\prime} 53^{\prime \prime}$ & $100^{\circ} 32^{\prime} 18^{\prime \prime}$ & 1086 \\
\hline Agam & Matur & KA-KPPT & $0^{\circ} 01^{\prime} 45^{\prime \prime}$ & $100^{\circ} 27^{\prime} 87^{\prime \prime}$ & 1049 \\
\hline Agam & Palembayan & KA-KHPH & $0^{\circ} 10^{\prime} 67^{\prime \prime}$ & $100^{\circ} 15^{\prime} 47^{\prime \prime}$ & 469 \\
\hline Padang Pariaman & Batang Anai & KPP-KPAU & $0^{\circ} 50^{\prime} 30^{\prime \prime}$ & $100^{\circ} 30^{\prime} 18^{\prime \prime}$ & 6 \\
\hline Padang Pariaman & Lubuk Alung & КРP-КРPP & $0^{\circ} 47^{\prime} 00^{\prime \prime}$ & $100^{\circ} 27^{\prime} 42^{\prime \prime}$ & 10 \\
\hline Tanah Datar & Batipuh & KTD-KHPI & $0^{\circ} 30^{\prime} 00^{\prime \prime}$ & $100^{\circ} 50^{\prime} 18^{\prime \prime}$ & 794 \\
\hline
\end{tabular}


Tanah Datar

Tanah Datar

Batipuh

Batipuh

Tanah Datar

Pariangan

KTD-KPPP
KTD-KMPS
KTD-KPK

0³1'70'"

033'23'

100 44'35"

$100^{\circ} 43^{\prime} 99^{\prime \prime}$

706

$0^{\circ} 29^{\prime} 20^{\prime \prime}$

$100^{\circ} 51^{\prime} 86^{\prime \prime}$

654

725

Table 2. Phenotypic Variability Based on Quantitative Characters of Glutinous Rice Plants in 3 different Regencies.

\begin{tabular}{|c|c|c|c|c|c|c|}
\hline $\mathrm{No}$ & Quantitative Characters & Mean & $S^{2}$ & SD & $2 \mathrm{SD}$ & Criteria \\
\hline$\overline{1}$ & Culm Length $(\mathrm{cm})$ & 121,422 & 63,511 & 7,969 & 15,938 & Large \\
\hline 2 & Many Leaves & 55,544 & 1,186 & 1,089 & 2,178 & Tight \\
\hline 3 & Root Length (cm) & 31,301 & 1,338 & 1,157 & 2,313 & Tight \\
\hline 4 & Many Tillers & 14,644 & 0,478 & 0,691 & 1,383 & Tight \\
\hline 5 & Many Productive Tillers & 12,544 & 0,201 & 0,447 & 0,894 & Tight \\
\hline 6 & Weight of 1000 Grain (g) & 31,222 & 1,661 & 1,289 & 2,578 & Tight \\
\hline 7 & Percentage Amilopektin (\%) & 81,044 & 7,684 & 2,772 & 5,544 & Large \\
\hline 8 & Age of Plants (days) & 146,667 & 37,653 & 6,136 & 12,272 & Large \\
\hline 9 & Productivity (tons) & 4,511 & 0,011 & 0,105 & 0,209 & Tight \\
\hline
\end{tabular}

If $\mathrm{S}^{2}>2 \mathrm{SD}$ means that the phenotypic variant is broad and if $\mathrm{S}^{2} \leq 2 \mathrm{SD}$ means the phenotypic variant is tight. (Pinaria, et al., 1995)

Table 3. Phenotypic Variability Based on Qualitative Characters of Glutinous Rice in 3 different Regencies (after scoring).

\begin{tabular}{|c|c|c|c|c|c|c|}
\hline $\mathrm{No}$ & Qualitative Characters & Mean & $\mathrm{S}^{2}$ & SD & $2 \mathrm{SD}$ & Criteria \\
\hline & Shape Plant & \multicolumn{2}{|c|}{2,000} & 0,666 & 0,816 & 1,632 \\
\hline 2 & Stem Color & 1,667 & 0,429 & 0,655 & 1,309 & Tight \\
\hline 3 & Leg Stem Color & 1,222 & 0,484 & 0,696 & 1,391 & Tight \\
\hline 4 & Auricle Color & 1,667 & 0,221 & 0,149 & 0,297 & Tight \\
\hline 5 & Ligule Color & 1,778 & 1,503 & 1,226 & 2,452 & Tight \\
\hline 6 & Leaf Color & 1,778 & 0.258 & 0,508 & 1,016 & Tight \\
\hline 7 & Leaf Surface & 2 & 0 & 0 & 0 & Tight \\
\hline 8 & Leaf Position & 1,333 & 0,501 & 0,708 & 1,416 & Tight \\
\hline 9 & Flag Leaf Angle & 1,444 & 0,553 & 0,744 & 1,487 & Tight \\
\hline 10 & Ligule Shape & 3 & 0 & 0 & 0 & Tight \\
\hline & Panicle Type & 1,444 & 1,053 & 1,026 & 2,052 & Tight \\
\hline 12 & Collapse Plant & 1,111 & 0,221 & 0,470 & 0,940 & Tight \\
\hline 13 & Category & 1,778 & 0,388 & 0,623 & 1,246 & Tight \\
\hline 14 & Grain Loss & 1 & 0 & 0 & 0 & Tight \\
\hline 15 & Grain Shape & 3,111 & 1,220 & 1,104 & 2,209 & Tight \\
\hline 16 & Grain Color & 2,889 & 5,720 & 2,392 & 4,783 & Large \\
\hline 17 & Glutinous Rice Color & 1,556 & 1,553 & 1,246 & 2,492 & Tight \\
\hline
\end{tabular}

If $\mathrm{S}^{2}>2$ SD means that the phenotypic variant is broad and if $\mathrm{S}^{2} \leq 2 \mathrm{SD}$ means the phenotypic variant is tight. (Pinaria, et al., 1995) 


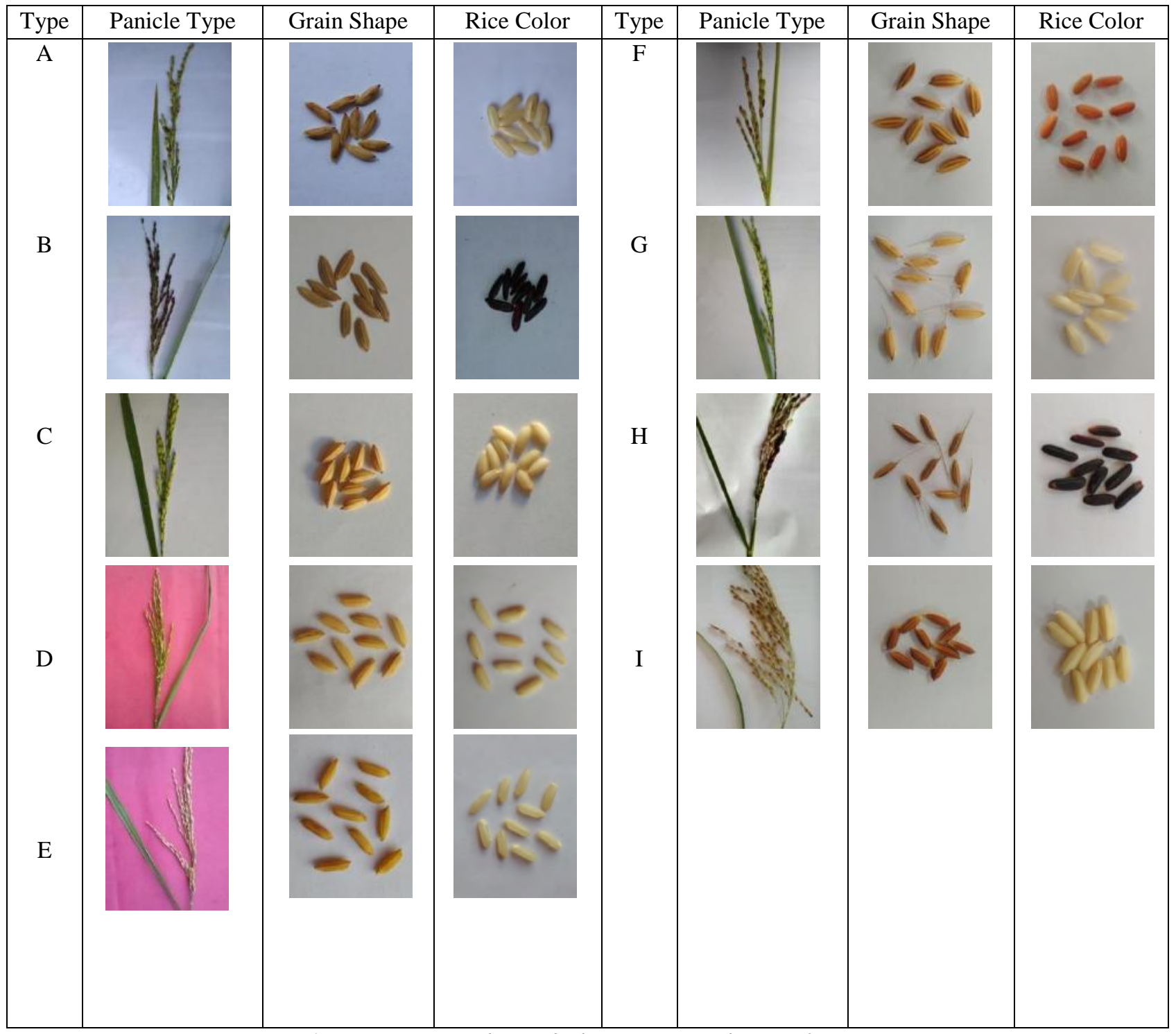

Fig.1: Data on Germplasm of Glutinous Rice Plants in 3 Regencies.

Information:

A. White Glutinous Rice 'Kuku Balam', Nagari Balingka, Districts of IV Koto, Regencies of Agam.

B. Black Glutinous Rice 'Puluik Hitam', Nagari Tigo Koto Silungkang, Districts of Palembayan, Regencies of Agam.

C. White Glutinous Rice 'Puluik Tinggi', Nagari Tigo Balai, Districts of Matur, Kab. Agam.

D. White Glutinous Rice 'Pulut Putih', Nagari Punggung Kasiak, Districts of Lubuk Alung, Regencies of Padang Pariaman.

E. White Glutinous Rice 'Anak Ulek', Nagari Sungai Buluh Utara, Districts of Batang Anai, Regencies of Padang Pariaman.

F. Red Glutinous Rice 'Puluk Sirah', Nagari Batipuh Baruah, Districts of Batipuh, Regencies of Tanah Datar.

G. White Glutinous Rice 'Puluk Putiah', Nagari Batipuh Baruah, Districts of Batipuh, Regencies of Tanah Datar.

H. Black Glutinous Rice 'Puluk Itam', Nagari Batipuh Baruah, Districts of Batipuh, Regencies of Tanah Datar.

I. White Glutinous Rice 'Kunyit', Nagari Tabek, Districts of Pariangan, Regencies of Tanah Datar. 


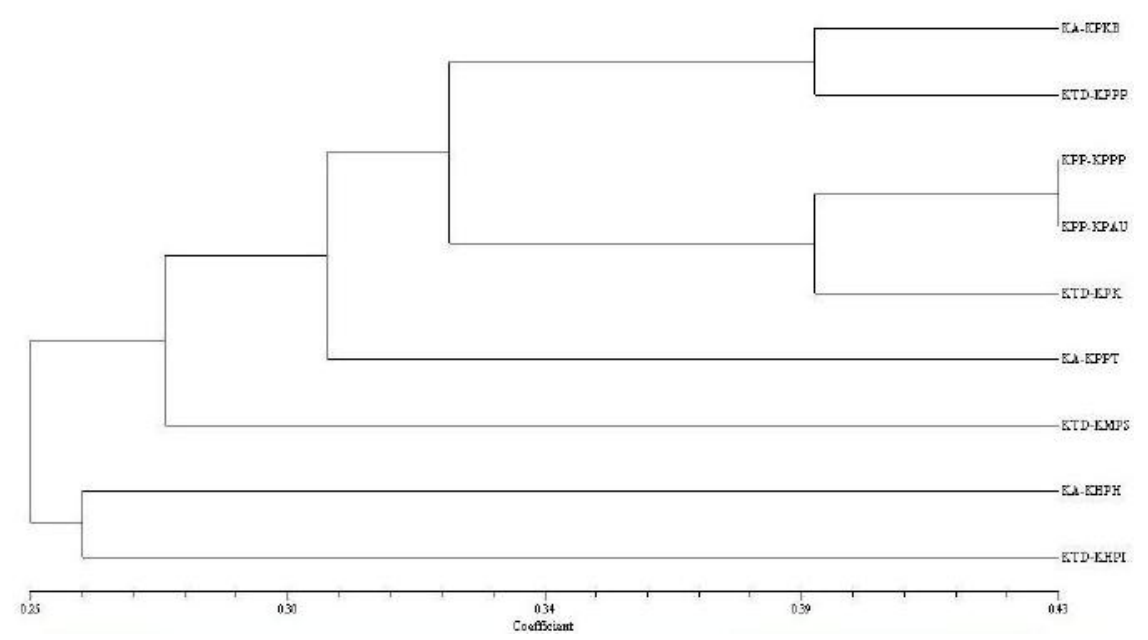

Fig.2: Similarity Analysis Dendogram Based on Quantitative and Qualitative Characters of 9 Glutinous Rice Germplasm in West Sumatra. Information : KA-KPKB = Kabupaten Agam - Ketan Putih Kuku Balam. KA-KPPT = Kabupaten Agam -

Ketan Putih Puluik Tinggi. KA-KHPH = Kabupaten Agam - Ketan Hitam Puluik Hitam. KPP-KPPP = Kabupaten Padang Pariaman - Ketan Putih Pulut Putih. KPP-KPAU = Kabupaten Padang Pariaman - Ketan Putih Anak Ulek. KTD-KPPP = Kabupaten Tanah Datar - Ketan Putih Puluk Putiah. KTD-KMPS = Kabupaten Tanah Datar - Ketan Merah Puluk Sirah. KTD-KHPI = Kabupaten Tanah Datar - Ketan Hitam Puluk Itam. KTD-KPK = Kabupaten Tanah Datar - Ketan Putih Kunyit.

\section{CONCLUSION}

Based on the results of exploration of local glutinous rice plants in Agam Regency, Padang Pariaman Regency and Tanah Datar Regency 9 species of germplasm of local glutinous rice plants were found.

Similarity analysis on 9 germplasm of local glutinous rice plants, through observations of quantitative and qualitative characters obtained similarity coefficients with the numbers $0.25-0.43$ or $25-43 \%$.

The highest similarity coefficient is found in KPPKPAU and KPP-KPPP which is 0.43 or $43 \%$. The magnitude of the similarity coefficient between KPPKPAU and KPP-KPPP shows the closer kinship level.

\section{REFERENCES}

[1] Daradjat, M., T. S. Silitonga and Nafisah. (2008). Availability of Germplasm for Improving Rice Varieties. Indonesian Center for Rice Research. Sukamandi.

[2] Fauza, H. (2005). Gambir (Uncaria gambir (hunter) Roxb.) Into Baihaki, A. (2006). The Current Condition of some Important Agricultural Commodity Germplasm. PPS Unpad- KNPN Deptan.

[3] IRRI. (1995). Parentage of IRRI Crosses. Plant Breeding, Genetics and Biochemistry Division. IRRI. Manila, Philipines. p.334.

[4] Kadan, R. S., E. T. Champaigne, G. M. Ziegler and O. A. Richard. (1997). Amylose and Protein Contents of Rice Cultivars as Related to Texture of Rice-based Fries. Journal of Food Science, vol. 62, Issue 4.

[5] Kush, G. S. (1995). Modern Variety Their Real Contribution to Food Supply Equity. Into Suardi, D. (2002). Rice Roots in Relation to Plant Tolerance to Drought and Yield. Biotechnology Research Center and Agricultural Genetic Resources. Bogor.

[6] Ramadhan, A. (2006). Development of Rice Mill Design. Mercu Buana University. Jakarta.

[7] Swasti, E., A. Syarif, I. Sulianyah dan N. E. Putri. (2007). Exploration and Identification of The Utilization at Rice Germplasm from West Sumatra. Technology Research Report I. Reseacrh Institution Andalas University. Padang.

[8] Syukur, M., Sujiprihati, S and R. Yunianti. (2012). Plant Breeding Techniques. Penebar Swadaya. Jakarta.

[9] Tedianto. (2012). Characterization of Pumpkin (Cucurbita moschata) Based on Morphological Markers and The Content of Protein, Carbohydrates and Fats at Various Altitudes. (Tesis). Sebelas Maret University. Surakarta. 